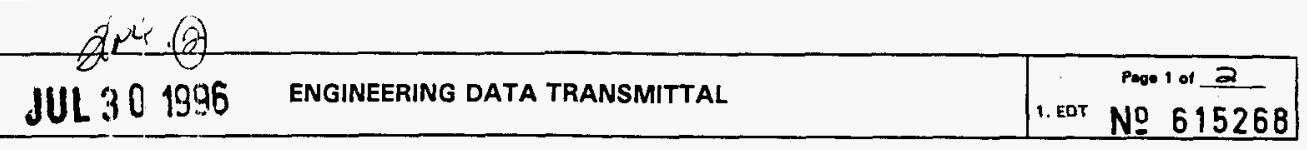

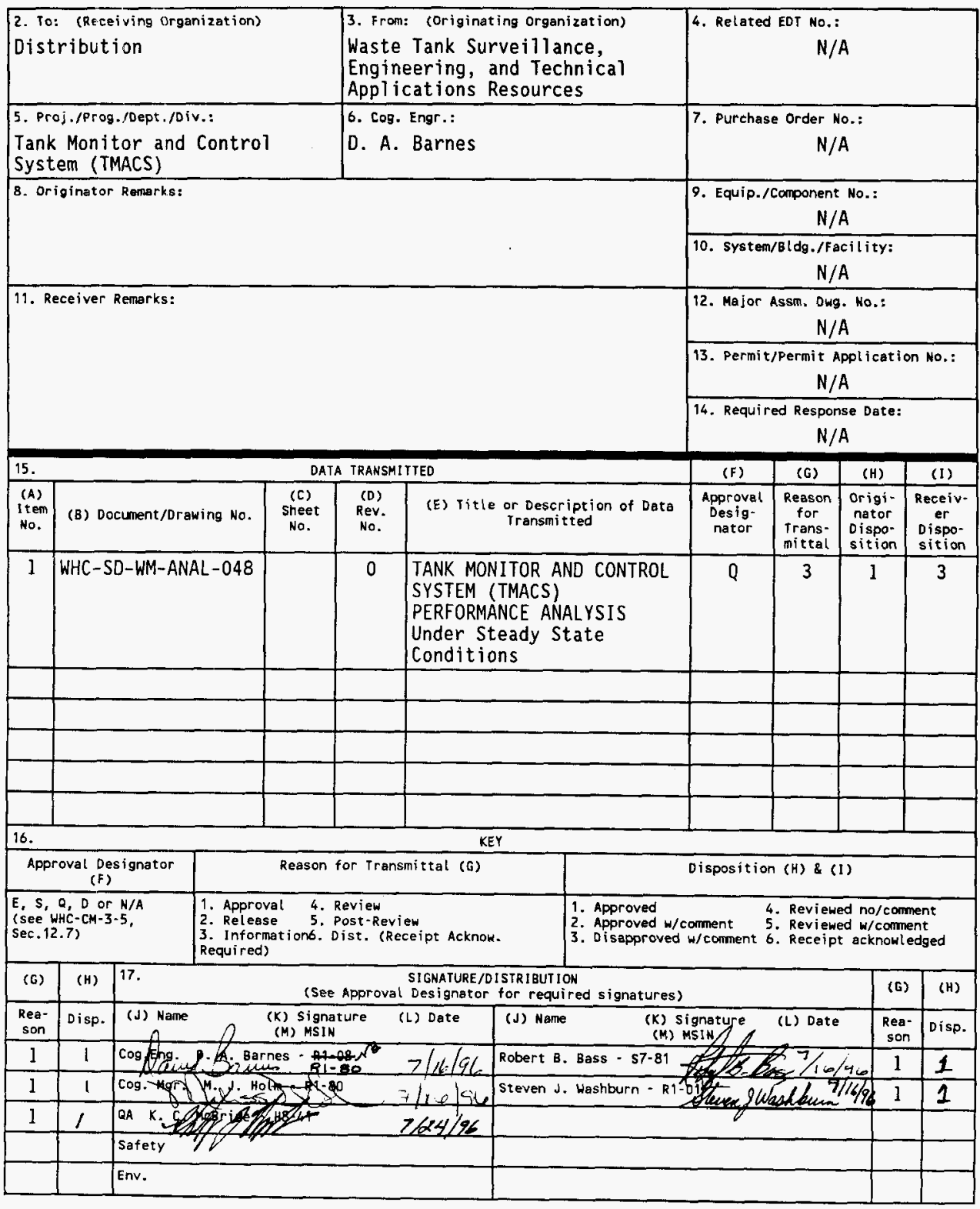


EDT No. 615268

\begin{tabular}{|c|c|c|c|c|}
\hline \multirow{2}{*}{\multicolumn{2}{|c|}{ 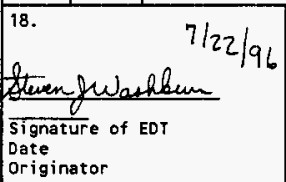 }} & 19. & \multirow{2}{*}{$\frac{\text { Nognizant managet-22.96 }}{\text { Cote }^{20.22}}$} & \multirow{2}{*}{ 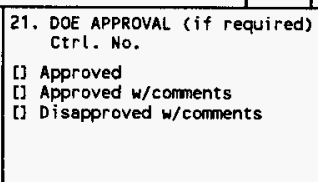 } \\
\hline & & $\begin{array}{l}\overline{\text { Authorized Representative }} \\
\text { Date } \\
\text { for Receiving Organization }\end{array}$ & & \\
\hline
\end{tabular}

BD-7400-172-2(04/94) GEF097 


\section{TANK MONITOR AND CONTROL SYSTEM (TMACS) PERFORMANCE ANALYSIS Under Steady State Conditions}

Robert B. Bass and Steven J. Washburn

Boeing Computer Services, Inc., Richland, WA 99352

U.S. Department of Energy Contract DE-AC06-87RL10930

EDT: 615268

Org Code: 62100

B\&R Code:
UC:

Charge Code: R60102

Total Pages: 2018 Kane $7 / 50 / 96$

Key Words: TMACS, Tank Monitor and Control System, Performance Analysis, Performance Measurement, W-314.

Abstract: A means to predict the performance impacts to the TMACS computer system prior to further increases in the TMACS point configuration is studied. A series of CPU utilization measurements are made on the TMACS production and development computers. These measurements are under steady-state operating conditions for $1 / 0$ point processing and remote terminal support. The data from these measurements are used to derive formulas that are then used to project CPU utilization for other configuration profiles. A configuration profile is described for (1) the current TMACS production system, (2) the maximum capacity of the current TMACS production system, and (3) a much larger target system, which reflects the anticipated size of the monitoring system for the upgrade project, $W-314$. The derived formulas are used to calculate CPU utilization for each of these configuration profiles. The formulas are validated by comparing the calculated with the measured results for the current production configuration. An analysis is performed that shows that the current system of 1,600 points can be expanded to 4,000 points without any changes. Furthermore, the current system can be expanded to 10,000 points to meet the requirements of the target system with the planned purchase of new-generation hardware and modifications to the logging and delta-check routines.

TRADEMARK DISCLAIMER. Reference herein to any specific commercial product, process, or service by trade name, trademark, manufacturer, or otherwise, does not necessarily constitute or imply its endorsement, recommendation, or favoring by the United States Government or any agency thereof or its contractors or subcontractors.

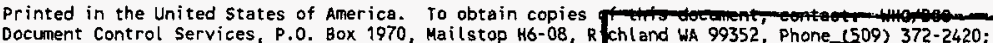
Fax (509) 376-4989.
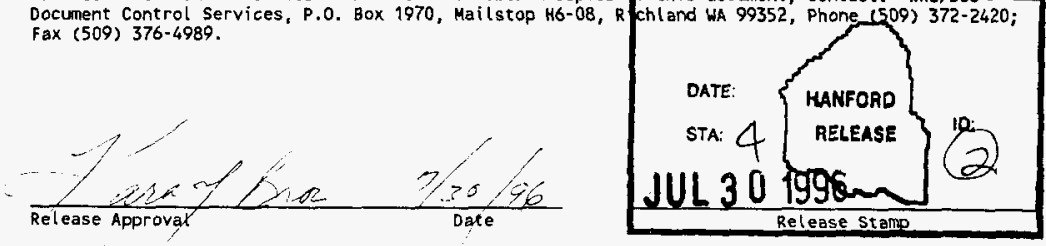

Approved for Public Release 
WHC-SD-WM-ANAL-048, Rev. 0

TANK MONITOR AND CONTROL SYSTEM (TMACS)

PERFORMANCE ANALYSIS

Under Steady-State Conditions

$$
\text { April 23, } 1996
$$

By

Robert B. Bass and Steven J. Washburn 
WHC-SD-WM-ANAL-048, Rev. 0

\section{Table of Contents}

1.0 EXECUTIVE SUMMARY . . . . . . . . . . . . . . . 3

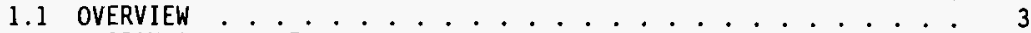

1.2 DESIGN OBJECTIVE . . . . . . . . . . . . . . . . . . 3

1.3 SYSTEM PROFILES . . . . . . . . . . . . . . . . . . 4

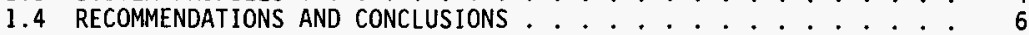

2.0 TECHNICAL ANALYSIS . . . . . . . . . . . . . . . 8

2.1 INTRODUCTION ..................... 8

2.2 CPU UTILIZATION MEASUREMENTS . . . . . . . . . . . . . . 8

2.2.1 Background Processing ................. 8

2.2 .2 1/0 Processing . . . . . . . . . . . . . . 9

2.2 .3 Point Processing ; . . . . . . . . . . . . . 9

2.2 .4 Remote Telewindow Processing ........... 10

APPENDIX A - TMACS Release 9.1 Profile .............. 11

APPENDIX B - Target System Profile . . . . . . . . . . . 12

APPENDIX C - Background CPU ................ 13

APPENDIX D - I/0 Processing .................. 14

APPENDIX E - Point Processing of Analogs ............ 15

APPENDIX F - Point Processing of Discretes ........... 16

APPENDIX G - Remote Window Processing . . . . . . . . . . . 17

'Telewindows is a registered trademark of Gensym Corporation. 
WHC-SD-WM-ANAL-048, Rev. 0

\subsection{EXECUTIVE SUMMARY}

\subsection{OVERYIEW}

The Tank Monitor and Control System (TMACS) monitors and collects various field instrument sensor readings (points) from the waste storage tanks in the 200 East and West Tank Farms and K Basins. TMACS provides continuous monitoring of status and alarm information. Currently, the TMACS workstations are in the Computer Automated Surveillance System (CASS) Central Facility and the East and West shift offices. Appendix A provides a profile of the TMACS configuration applicable to this report.

During January and February of 1996, the TMACS development team conducted an analysis of the TMACS central computer system. The purpose of this analysis was to develop a means to project the performance impacts to the TMACS computer system prior to further increases in the TMACS point configuration.

In the last half of 1995, TMACS experienced system performance problems that heightened the need for performance measurements. During that time problems with the TMACS vendor's software product, $\mathbf{G 2}^{2}$, from the Gensym Corporation, caused a rapid increase in CPU utilization. This required TMACS personnel to shut down and restart the system approximately every 10 to 15 days to restore acceptable performance levels.

Installation of the latest release of $\mathrm{G}^{(}{ }^{(1)}$ (Release 4.0 ) permanently remedied the problem of increasing CPU utilization over time. It also fixed another problem TMACS had encountered, large memory "leakage" over time. Currently, the TMACS's CPU utilization and memory usage is stable and no longer requires periodic shutdowns and restarts.

\subsection{DESIGN OBJECTIVE}

In this document we present performance measurements for our current system configuration and the projected TMACS target configuration. TMACS's primary performance requirement is to maintain CPU percent utilization at or below 50 CPU-\% during steady-state operation.

Throughout this document we use the unit of measurement "CPU-\%" to indicate CPU percent utilization. This unit represents the actual central processing unit (CPU) time the computer's operating system allocates to the G2 ${ }^{\circledR}$ program, as a percent of maximum time available. A measurement of $50 \mathrm{CPU}$ \% (the design objective) would indicate that the computer's CPU expends only half the time the operating system has made available to $\mathrm{G2}^{(B)}$.

\footnotetext{
${ }^{2} \mathrm{G} 2$ is a registered trademark of Gensym Corporation.
} 
WHC-SD-WM-ANAL-048, Rev. 0

The following four functional processing areas define steady-state processing in TMACS:

(I) Background Processing - processing associated with system overhead. Background processing is dependent on the number of points and other items configured in TMACS that require $\mathrm{G2}^{(}{ }^{\oplus}$ to expend CPU time. It is independent of activity that operators initiate and activity from field instrumentation;

(2) I/O Processing - processing associated with system interfaces to external field instrument inputs and outputs (e.g., Acromag, Enraf);

(3) Point Processing - processing associated with delta checking ${ }^{3}$, instrument limit checking, alarm limit checking, rate-of-change limit checking, and sensor logging to disk for analog and discrete points;

(4) Remote Telewindow ${ }^{\circledR}$ Processing - processing required to maintain remote TMACS workstation displays.

This report does not include an analysis of the effects on CPU utilization due to transient processing (e.g., alarm processing, rate-of-change) and operator functions (e.g., trend displays, al arm acknowledgements). We have assumed that such transient processing will be adequately handled by the $50 \mathrm{CPU}-\%$ reserve that will be available if TMACS meets the design objective. We have justified this assumption based on observations of the behavior of a previous version of TMACS; the system was running at $88 \mathrm{CPU}-\%$ for several months and could handle all transient processing. We anticipate that we will provide more formal and detailed transient performance measurements for TMACS as the system grows.

\subsection{SYSTEM PROFILES}

The table below provides a profile of the following TMACS system configurations:

- The current system load (TMACS Release 9.1, January 1996);

- A maximum capacjty load based on the current system running at $50 \mathrm{CPU}-\%$;

- The projected target system load, which meets the anticipated requirements of Project $W-314$ (see Appendix B for the description of the point-processing profile).

3 delta means the threshold value (determined by sensor type) by which the sensor reading must change for the sensor to be processed. 
WHC-SD-WM-ANAL-048, Rev. 0

\begin{tabular}{|c|c|c|c|}
\hline $\begin{array}{l}\text { System } \\
\text { Parameter }\end{array}$ & $\begin{array}{c}\text { Current System } \\
\text { Loading }\end{array}$ & $\begin{array}{c}\text { Current System e } 50 \\
\text { CPU-\% }\end{array}$ & $\begin{array}{c}\text { Target System } \\
\text { Loading }\end{array}$ \\
\hline $\begin{array}{l}\text { Number of } \\
\text { Points }\end{array}$ & $\begin{array}{ll} & 1,640 \\
\text { Analogs: } & 1590 \\
\text { Discretes: } & 50\end{array}$ & $\begin{array}{ll} & 4,000 \\
\text { Analogs: } & 3000 \\
\text { Discretes: } & 1000\end{array}$ & \begin{tabular}{ll}
\multicolumn{2}{c}{10,000} \\
Analogs: & 6000 \\
Discretes: & 4000
\end{tabular} \\
\hline $\begin{array}{l}\text { Average } \\
\text { Polling } \\
\text { Frequency }\end{array}$ & $\begin{array}{l}\text { Analogs: } \\
8.4 \mathrm{pts} / \mathrm{sec} \\
\text { Discretes: } \\
1.5 \mathrm{pts} / \mathrm{sec}\end{array}$ & $\begin{array}{l}\text { Analogs: } \\
60 \mathrm{pts} / \mathrm{sec} \\
\text { Discretes: } \\
100 \mathrm{pts} / \mathrm{sec}\end{array}$ & $\begin{array}{l}\text { Analogs: } \\
400 \mathrm{pts} / \mathrm{sec} \\
\text { Discretes: } \\
625 \mathrm{pts} / \mathrm{sec}\end{array}$ \\
\hline $\begin{array}{l}\text { Number of } \\
\text { Device } 1 / 0 \\
\text { Ports }\end{array}$ & 6 & 12 & 16 \\
\hline $\begin{array}{l}\text { Instrument } \\
\text { Readings } \\
\text { Input Rate } \\
\text { from Bridge } \\
\text { to } \mathrm{G}^{\circledR}\end{array}$ & $\begin{array}{l}\text { Analogs: } \\
8.4 \text { pts } / \mathrm{sec} \\
\text { Discretes: } \\
<0.1 \mathrm{pts} / \mathrm{sec}\end{array}$ & $\begin{array}{l}\text { Analogs: } \\
60 \mathrm{pts} / \mathrm{sec} \\
\text { Discretes: } \\
4 \mathrm{pts} / \mathrm{sec}\end{array}$ & $\begin{array}{l}\text { Analogs: } \\
400 \mathrm{pts} / \mathrm{sec} \\
\text { Discretes: } \\
10 \mathrm{pts} / \mathrm{sec}\end{array}$ \\
\hline $\begin{array}{l}\text { Average } \\
\text { Instrument } \\
\text { Readings } \\
\text { Input Rate } \\
\text { per Port }\end{array}$ & $1.4 \mathrm{pts} / \mathrm{sec} /$ port & $5 \mathrm{pts} / \mathrm{sec} / \mathrm{port}$ & $26 \mathrm{pts} / \mathrm{sec} /$ port \\
\hline $\begin{array}{l}\text { Point } \\
\text { Processing } \\
\text { (delta not } \\
\text { exceeded or } \\
\text { no state } \\
\text { change) }\end{array}$ & $\begin{array}{l}\text { Analogs: } \\
8.1 \mathrm{pts} / \mathrm{sec} \\
\text { Discretes: } \\
0 \mathrm{pts} / \mathrm{sec}\end{array}$ & $\begin{array}{l}\text { Analogs: } \\
50 \mathrm{pts} / \mathrm{sec} \\
\text { Discretes: } \\
0 \mathrm{pts} / \mathrm{sec}\end{array}$ & $\begin{array}{l}\text { Analogs: } \\
360 \text { pts } / \mathrm{sec} \\
\text { Discretes: } \\
0 \text { pts } / \mathrm{sec}\end{array}$ \\
\hline $\begin{array}{l}\text { Point } \\
\text { Processing } \\
\text { (delta } \\
\text { exceeded or } \\
\text { state } \\
\text { changed) }\end{array}$ & $\begin{array}{l}\text { Analogs: } \\
0.3 \mathrm{pts} / \mathrm{sec} \\
\text { Discretes: } \\
<0.1 \mathrm{pts} / \mathrm{sec}\end{array}$ & $\begin{array}{l}\text { Analogs: } \\
10 \mathrm{pts} / \mathrm{sec} \\
\text { Discretes: } \\
4 \mathrm{pts} / \mathrm{sec}\end{array}$ & $\begin{array}{l}\text { Analogs: } \\
40 \mathrm{pts} / \mathrm{sec} \\
\text { Discretes: } \\
10 \mathrm{pts} / \mathrm{sec}\end{array}$ \\
\hline $\begin{array}{l}\text { Number of } \\
\text { Remote } \\
\text { Terminals }\end{array}$ & 4 & 6 & 20 \\
\hline $\begin{array}{l}\text { CPU } \\
\text { Utilization }\end{array}$ & $15 \mathrm{CPU}-\%$ & $50 \mathrm{CPU}-\%$ & $200 \mathrm{CPU}-\%$ \\
\hline
\end{tabular}

The CPU utilization figures in the table above are calculations from formulas that fit the performance measurement data. Section 2.0, Technical Analysis explains the measurement. We also took several measurements of the current production system's CPU utilization over time, under steady-state conditions, using the $\mathrm{G}^{(}{ }^{\circledR}$ performance meters. The calculated CPU utilization value for 
the current system loading configuration matches actual measured values for the current production system within $+/-1.0 \mathrm{CPU}-\%$. This close correlation between the calculated value and the measured values helps validate and increase our confidence in the formulas.

The next table shows the breakdown of the CPU utilizations, by functional processing area, for each of the three system configuration profiles in the previous table.

\begin{tabular}{|c|c|c|c|}
\hline & & $\begin{array}{c}\text { CPU Uti]lzation } \\
(\text { CPU-\%) }\end{array}$ & \\
\hline $\begin{array}{c}\text { Functional Processing } \\
\text { Area }\end{array}$ & $\begin{array}{c}\text { Current System } \\
\text { Loading }\end{array}$ & $\begin{array}{c}\text { Current System } \\
\text { e } 50 \text { CPU-\% }\end{array}$ & Target System \\
\hline Background Processing & 8 & 14 & 29 \\
\hline I/0 Processing & 3 & 6 & 19 \\
\hline Point Processing & 2 & 26 & 140 \\
\hline Remote Terminals & 2 & 4 & 12 \\
\hline Total CPU Utilization & 15 & 50 & 200 \\
\hline
\end{tabular}

\subsection{RECOMMENDATIONS AND CONCLUSIONS}

Our analysis shows that the current TMACS will not meet our design objective to stay at or below $50 \mathrm{CPU}$ \%, during steady-state operation, for the target system loading. However, while making our performance measurements we identified several areas of improvement that could immediateiy lower CPU utilization on the main TMACS processor. These include:

- Background Processing - background processing in a 10,000 point target system will require $29 \mathrm{CPU}-\%$. We can reduce this significantly, to approximately $4 \mathrm{CPU}-\%$, by replacing each point's old-style trend charts and its accompanying time/date displays. The new-style trend charts, which are available in $\mathrm{GQ}^{\circledR}{ }^{\mathbb{B}}$ 's Release 4.0 , are more efficient and have an improved time-axis label. The format of the new time-axis labels obviates the use of time/date displays;

- Logging to disk - the point processing routines expend over $50 \%$ of their time logging points to disk. We can develop a GSI ${ }^{4}$ driver for the slave workstation that would off-load most of the logging overhead to the slave processor. We estimate that this would reduce CPU utilization for the target system by approximately $15 \mathrm{CPU}-\%$;

\footnotetext{
"GSI is a trademark of Gensym Corporation.
} 
- Analog Delta Check - the analog point processing routine expends approximately $30 \%$ of its time on the delta check. The percent CPU utilization in the target system would drop by approximately $95 \mathrm{CPU}-\%$ if we move the delta check from the analog point processing routine in the G2 ${ }^{(i)}$ code to the bridge code. The bridge code would then only send those analog points that exceed delta. This is similar to the way the bridge code now processes discrete points, which it only sends to $G_{2}{ }^{\circledR}$ when there is a state change.

These modifications alone would reduce the projected CPU utilization on the target system from $200 \mathrm{CPU}-\%$ to $65 \mathrm{CPU}-\%$. TMACS could operate below the design objective of $50 \mathrm{CPU} \%$ with its next hardware upgrade. Even today's technology can provide the means to meet this performance level. For example, the Sun ${ }^{5}$ U1traSPARC ${ }^{6}$ provides almost twice the CPU processing power as the $\operatorname{SUn}^{\circledR}$ SPARC20 $^{\circledR}$.

Purchase of new computer hardware (or upgrades) is consistent with the TMACS project plan to upgrade the main computer system periodically, on a two to three year cycle. This approach provides a means to maintain system reliability and to meet growth demands. The TMACS project also plans to continue to exercise the option in the maintenance agreement with the $\mathrm{G}^{\circledR}$ vendor to implement future releases of $\mathrm{G}^{(\oplus)}$.

Since TMACS went online, in January of 1993, on a Sun ${ }^{\circledR}$ SPARCstation ${ }^{7}$ platform running $\mathrm{G}_{2}{ }^{\circledR}$ Version 2.0 , we have seen a tenfold increase in processing capability. This increase is the result of a combination of upgrading hardware, implementing the vendor's latest release of $\mathrm{G} 2^{\circledR}$, and working to optimize the system's processing procedures.

We are currently projecting that for the balance of FY 1996 we will be adding approximately 900 discretes and 500 analogs. This will bring TMACS up to a little over 3000 points (2090 analogs, 950 discretes), which is still within our projected system capacity. We would expect the CPU utilization of the system, with this point count, one more serial port, one more remote terminal and 10 points/second ( 7 analog, 3 discrete) exceeding delta, to be approximately $29 \mathrm{CPU}-\%$.

${ }^{5}$ Sun is a registered trademark of Sun Microsystems, Inc.

GUtraSPARC is a registered trademark of SPARC International, Inc., and licensed exclusively to Sun Microsystems, Inc.

${ }^{7}$ SPARCstation is a registered trademark of SPARC International, Inc., and licensed exclusively to Sun Microsystems, Inc. 


\subsection{TECHNICAL ANALYSIS}

\subsection{INTRODUCTION}

A variety of measurements on the TMACS production and development systems provided the data to project CPU usage for various point configurations. This section describes how we conducted these measurements and presents the formulas we derived from the data to make our performance projections.

We conducted all tests using TMACS Release 9.1, with $\mathrm{G}_{2}{ }^{\oplus}$ Version 4.0 , Revision 1, running under Sun ${ }^{(}$Solaris $^{8} 2.4$. The production system is a Sun ${ }^{(1)}$ SPARC20 $20^{\circledR} / 100 \mathrm{Mhz}$ machine. The development system is a Sun Microsystems SPARC20 ${ }^{\circledR} / 75 \mathrm{Mhz}$, dual CPU workstation.

\subsection{CPU UTILIZATION MEASUREMENTS}

The CPU utilization measurements covered each of the functional processing areas that Section 1.0 describes: Background, I/0, Point, and Remote Telewindow ${ }^{(}$Processing. $G 2^{(1)}$ procedures (software programs) generated the CPU utilization measurements. These procedures ran on the TMACS development system.

Automated $\mathrm{G}^{(}{ }^{\oplus}$ procedures, which are now part of TMACS, measured background and point processing CPU utilization. These procedures also compiled the results in tables for subsequent publication.

The Acromag bridge and Acromag emulation software generated $1 / 0$ processing data. Output from the bridge programs went to the development system via the G2 ${ }^{(\oplus)}$ vendor's GSI ${ }^{\text {TM }}$ interface package. This is the same arrangement the TMACS production system uses to interface to live data in the field.

Observations of the CPU utilization meters on the TMACS production system also provided measurements of remote Telewindow ${ }^{\circledR}$ processing. We compared data from these measurements to those from the development system to validate development system and calculated results.

\subsubsection{Background Processing}

The background processing procedure measured system background CPU utilization as a function of the number of analog and digital points in TMACS. Currentiy there are approximately 1600 points in TMACS. The target system is defined to have 10,000 points. Appendix $C$ shows the results from these measurements, which includes a table for various point counts ranging from 1600 to 10,000 .

\footnotetext{
${ }^{8}$ Solaris is a trademark of Sun Microsystems, Inc.
} 
The following formula fits the measurement data:

Background CPU Usage $(\mathrm{CPU}-\%)=8.1+$

$0.0024 *$ (<No. of Analog Points $\rangle-1589)+$

0.0026 * (<No. of Discrete Points - 49)

Example: For a configuration with 3000 analog points and 1000 discrete points, the CPU usage for just background processing would be as follows:

$$
\begin{aligned}
\text { Background CPU usage }(\text { CPU-\%) }=8.1 & +0.0024 *(3000-1589) \\
& +0.0026 *(1000-49) \\
& =14 \mathrm{CPU}-\%
\end{aligned}
$$

\subsubsection{I/0 Processing}

The I/O processing procedure measured the CPU utilization necessary to support connection to I/0 ports. The procedure used the Acromag bridge and simulated analog points. Appendix $D$ shows the table for points versus number of ports. The CPU usage per $1 / 0$ port was approximately 0.5 CPU $\%$.

The formulas we derived for determining CPU utilization for any number of I/0 ports, at various data throughput rates are the following:

I/O Processing CPU Usage 16 pts $/ \mathrm{sec}(\mathrm{CPU}-\%)=0.5 *\langle$ No. of $1 / 0$ Ports $>$

I/0 Processing CPU Usage 32 pts $/ \mathrm{sec}(\mathrm{CPU}-\%)=1.2$ * 3 No. of I/0 Ports $>$

I/0 Processing CPU Usage $48 \mathrm{pts} / \mathrm{sec}(\mathrm{CPU}-\%)=1.6 *\langle\mathrm{No}$. of I/0 Ports $\rangle$

$1 / 0$ Processing CPU Usage 64 pts/sec $(\mathrm{CPU}-\%)=2.7 *\langle$ No. of $1 / 0$ Ports $>$

Example: For a configuration with 12 ports each with a data throughput of less than 16 points/sec, the CPU usage for just $1 / 0$ processing would be as follows:

$1 / 0$ Processing CPU usage $(\mathrm{CPU}-\%)=0.5 * 12=\underline{6 \mathrm{CPU}-\%}$

\subsubsection{Point Processing}

The point processing procedures measured the CPU utilization required to process analog and digital points. The procedures also provided CPU utilization measurements of the functional components that make up point processing, which include the value update, delta check (analog only), alarm limit checks, rate-of-change check (analog only), and logging to disk. These measurements were for steady-state conditions, i.e., no point exceeded its alarm or rate-of-change limits. Appendices $E$ and $F$ show the results tables of these measurements. Note Appendix E refers to analog points as "Continuous" points. 
The formula we derived for determining CPU utilization for any number of points, using the current TMACS software/hardware configuration is the following:

Point Processing CPU Usage (CPU-\%) =

0.27 * (No. of Analog points/sec that do not exceed the delta limit) + 0.89 * (No. of Analog points/sec that exceed the delta limit) +

0.77 * (No. of Discrete points/sec that change state)

Example: For a configuration that processes 50 analog points/second that do not exceed the delta limit, 10 analog points/second that do exceed the delta limit, and 4 discrete points/second that change state, the CPU usage for just point processing would be as follows:

Point Processing CPU Usage (CPU-\%) $=(0.27 * 50)+(0.89 * 10)+(0.77 * 4)$ $=26 \mathrm{CPU}-\%$

\subsubsection{Remote Telewindow $\left.{ }^{(}\right)$Processing}

The remote Telewindow ${ }^{(0)}$ processing procedure measured CPU utilization required to support remote operator terminals. This procedure ran on the TMACS development system. Appendix $G$ gives the CPU utilization figures recorded when Telewindows $\left.{ }^{(}\right)$were in use and when they were not. The measurement method was to find the difference between the system's average CPU utilization with several remote windows connected and with no remote windows connected.

The formula we derived for determining CPU utilization for any number of Telewindows ${ }^{\circledR}$ processes, using the current TMACS software/hardware configuration, is the following:

Remote Telewindow ${ }^{(B)}$ CPU Usage $(C P U-\%)=$

$$
0.6 \text { * (Number of Remote Telewindow }{ }^{(0)} \text { Terminals) }
$$

Example: For a configuration with 6 remote Telewindows ${ }^{\circledR}$ terminals, the CPU usage for all remote terminal processing would be as follows:

Remote Telewindows ${ }^{\circledR} \mathrm{CPU}$ usage $(\mathrm{CPU}-\%)=0.6 * 6=\underline{3.6 \mathrm{CPU}-\%}$ 


\section{APPENDIX A - TMACS Release 9.1 Profile}

IMACS Profile (as of 1/24/96):

Central Computers - 1

Application Software - Gensym Corp. G2 ${ }^{\circledR}$, Release 4.0 , Revision I

Current Release -

TMACS, Release 9.1

RTUs -

106 Acromag, Series 4300 ,

System Start-Up - January 29, 1993

Tanks being Monitored: 109 out of 177 (not including $k$ Basins)

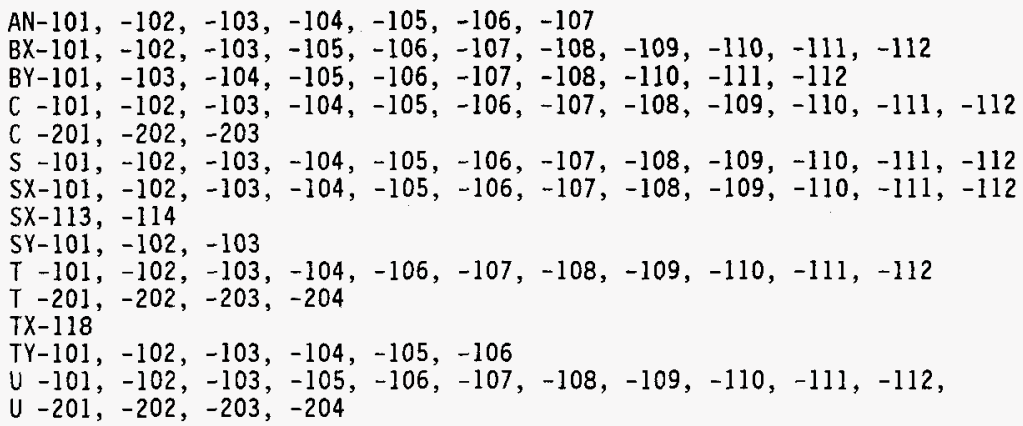

Systems Being Monitored:

100-K Basins (K East, $K$ West) 3 discretes

Standard Hydrogen Monitoring System (SHMS) 36 discretes

Instrumentation Being Monitored: 1570 sensors

$\begin{array}{lrl}\text { Continuous Sensors: } & 1531 & \\ \text { Temperature sensors: } & 1350 & (1,082 \mathrm{TCs}, 62 \mathrm{RTDs}, 206 \text { ref TCs }) \\ \text { Pressure sensors: } & 18 & \\ \text { Level sensors: } & 109 & \text { (23 ENRAFs, 86 via SACS) } \\ \text { Hydrogen sensors: } & 34 & \\ \text { Flow sensors: } & 20 & \\ \text { Discrete Sensors: } & 39 & \left(18 \mathrm{H}_{2}, 18 \text { Trouble, 3 K Basin) }\right.\end{array}$


WHC-SD-WM-ANAL-048, Rev. 0

\section{APPENDIX B - Target System Profile}

Target System Point Configuration

\begin{tabular}{|c|c|c|c|}
\cline { 2 - 4 } \multicolumn{1}{c|}{} & \multicolumn{3}{c|}{ ANALOG POINTS } \\
\hline $\begin{array}{c}\text { Polling } \\
\text { Rate } \\
\text { (seconds) }\end{array}$ & $\begin{array}{c}\text { Number of } \\
\text { Points } \\
\text { Configured }\end{array}$ & $\begin{array}{c}\text { Number of } \\
\text { Points/Second } \\
\text { (Polled by Bridges) }\end{array}$ & $\begin{array}{c}\text { Number of } \\
\text { Points/Second that } \\
\text { Exceed Delta Limit }\end{array}$ \\
\hline 1 & 200 & 200 & 20 \\
\hline 10 & 1,800 & 180 & 18 \\
\hline 60 & 1,000 & 15 & 1.5 \\
\hline 600 & 3,000 & 5 & 0.5 \\
\hline \hline TOTALS & 6,000 & 400 & 40 \\
\hline
\end{tabular}

\begin{tabular}{|c|c|c|c|}
\cline { 2 - 4 } \multicolumn{1}{c|}{} & \multicolumn{3}{|c|}{ DISCRETE POINTS } \\
\hline \hline $\begin{array}{c}\text { Polling } \\
\text { Rate } \\
\text { (seconds) }\end{array}$ & $\begin{array}{c}\text { Number of } \\
\text { Points } \\
\text { Configured }\end{array}$ & $\begin{array}{c}\text { Number of } \\
\text { Points/Second } \\
\text { (Polled by Bridges) }\end{array}$ & $\begin{array}{c}\text { Number of } \\
\text { Points/Second that } \\
\text { Change State }\end{array}$ \\
\hline \hline 1 & 250 & 250 & 4 \\
\hline 10 & 3,750 & 375 & 6 \\
\hline \hline TOTALS & 4,000 & 625 & 10 \\
\hline
\end{tabular}


WHC-SD-WM-ANAL-048, Rev. 0

APPENDIX C - Background CPU

Background CPU Utilization versus

Number of Analog and Discrete Points in System

\begin{tabular}{|c|c|c|c|c|c|c|}
\hline $\begin{array}{l}\mathrm{No}, \text { of } \\
\text { Cont. } \\
\text { Points }\end{array}$ & $\begin{array}{l}\text { No of } \\
\text { Dscrt. } \\
\text { Points }\end{array}$ & & $\begin{array}{l}\text { Average } \\
(10 \text { Min. })\end{array}$ & $\begin{array}{l}\text { Minimum } \\
(10 \mathrm{Min})\end{array}$ & $\begin{array}{l}\text { Maximum } \\
(10 \mathrm{Min})\end{array}$ & std Dev $(10$ \\
\hline 1590 & 50 & BKGO & 8.138 & 6.206 & 11.523 & $9.2 \%$ \\
\hline 2000 & 50 & BKGD & 9.107 & 7.324 & 10.42 & $7.9 \%$ \\
\hline 2000 & 2000 & BKGD & 13.949 & 11.867 & 15.5 & $4.8 \%$ \\
\hline 3000 & 2000 & BKGD & 16.432 & 14.106 & 28.547 & $8.8 \%$ \\
\hline 3000 & 3000 & BKGD & 18.908 & 16.801 & 21.667 & $3.7 \%$ \\
\hline 4000 & 3000 & BKGD & 21.292 & 19.513 & 24.105 & $3.4 \%$ \\
\hline 4000 & 4000 & BKGD & 23.711 & 22.064 & 25.754 & $2.7 \%$ \\
\hline 5000 & 4000 & BKGD & 26.587 & 24.775 & 28.909 & $2.4 \%$ \\
\hline 5000 & 5000 & BKGD & 28.855 & 26.73 & 47.511 & $7.5 \%$ \\
\hline Pts/Sec & 20 & from - to & $\mathrm{kb} / \mathrm{cnt}-\mathrm{pt}$ & bkgd/con-pt & $\mathrm{kb} / \mathrm{dsc}-\mathrm{pt}$ & bkgd/dsc-pt \\
\hline Delta & 0.0 & $2000-3000$ & 9.5 & 0.0025 & 11.3 & 0.0025 \\
\hline $\begin{array}{l}\text { Pt. } \\
\text { Proc. }\end{array}$ & True & $3000-4000$ & 22.1 & 0.0024 & 12.2 & 0.0024 \\
\hline $\begin{array}{l}\text { Alarm } \\
\text { Proc. }\end{array}$ & True & $4000-5000$ & 19.7 & 0.0029 & 14.5 & 0.0023 \\
\hline $\begin{array}{l}\text { ROC } \\
\text { Proc. }\end{array}$ & True & & & & & \\
\hline $\begin{array}{l}\text { Log } \\
\text { Proc. }\end{array}$ & True & Average & 17.1 & 0.0026 & 12.7 & 0.0024 \\
\hline
\end{tabular}




$$
\begin{gathered}
\text { WHC-SD-WM-ANAL-048, Rev. } 0 \\
\text { APPENDIX D - I/O Processing } \\
\text { CPU Utilization } \\
\text { for } \\
\text { I/O Processing Functions } \\
\text { with } \\
\text { Analog Points }
\end{gathered}
$$

\begin{tabular}{|c|c|c|c|c|}
\hline $\begin{array}{c}\text { \# of } \\
\text { Ports }\end{array}$ & $\begin{array}{c}16 \\
\text { Points/Second }\end{array}$ & Points/Second & Points/Second & Points/second \\
\hline 0 & 8.3 & 8.3 & 8.3 & 8.3 \\
\hline 1 & 9.1 & 9.5 & 9.9 & 10.1 \\
\hline 2 & 9.8 & 10.5 & 11.8 & 11.2 \\
\hline 3 & 10.0 & 11.7 & 13.0 & 12.8 \\
\hline 4 & 10.5 & 13.0 & 14.8 & 14.6 \\
\hline $\begin{array}{c}\text { LINEAR } \\
\text { SLOPE }\end{array}$ & 0.5 & 1.2 & 1.6 & 2.7 \\
\hline
\end{tabular}


WHC-SD-WM-ANAL-048, Rev. 0

\section{APPENDIX E - Point Processing of Analogs}

CPU Utilization

for

Point Processing Functions

with

Analog Points

\begin{tabular}{|c|c|c|c|c|c|}
\hline $\begin{array}{l}\text { Pt. Proc. } \\
\text { Function }\end{array}$ & & $\begin{array}{l}\text { Average } \\
\text { (10 Min) }\end{array}$ & $\begin{array}{l}\text { Minimum, } \\
\text { (10 Min.) }\end{array}$ & $\begin{array}{l}\text { Maximum } \\
\text { (10 Min.) }\end{array}$ & $\begin{array}{l}\text { Std Dev } \\
(10 \mathrm{Min} .)\end{array}$ \\
\hline A]1 Funcs & $\% \mathrm{CPU}$ & 27.038 & 25.26 & 31.994 & $2.73 \%$ \\
\hline W/o Logging & $\% \mathrm{CPU}$ & 16.595 & 14.715 & 17.723 & $3.33 \%$ \\
\hline W/O ROC & $\% \mathrm{CPU}$ & 15.215 & 12.842 & 16.86 & $4.40 \%$ \\
\hline w/o Alarm & $\% \mathrm{CPU}$ & 14.723 & 12.929 & 16.543 & $4.33 \%$ \\
\hline$<$ Delta & $\% \mathrm{CPU}$ & 12.683 & 11.079 & 16.759 & $5.19 \%$ \\
\hline w/o Pt Proc & $\% \mathrm{CPU}$ & 9.185 & 7.17 & 14.912 & $8.93 \%$ \\
\hline w/o Rule & $\% \mathrm{CPU}$ & 8.867 & 7.155 & 9.952 & $6.00 \%$ \\
\hline BKGD & $\% \mathrm{CPU}$ & 8.221 & 6.79 & 12.292 & $6.98 \%$ \\
\hline $\begin{array}{l}\text { Summary } \\
\text { Breakdown }\end{array}$ & $\% \mathrm{CPU}$ & & $\begin{array}{l}\text { Pt. Proc. } \\
\text { Breakdown }\end{array}$ & $\% \mathrm{cpu} / \mathrm{pt} / \mathrm{sec}$ & \\
\hline Pt Proc & 17.85 & $66.0 \%$ & Update Pt. & 0.17 & $19.6 \%$ \\
\hline Rule Proc & 0.32 & $1.2 \%$ & Delta Check & 0.10 & $11.4 \%$ \\
\hline 1/0 Proc & 0.65 & $2.4 \%$ & Alarm Chk & 0.02 & $2.8 \%$ \\
\hline Bkgd & 8.22 & $30.4 \%$ & ROC Check & 0.07 & $7.7 \%$ \\
\hline & & & Log to Disk & 0.52 & $58.5 \%$ \\
\hline Total: & 27.04 & $100.0 \%$ & Total: & 0.89 & $100.0 \%$ \\
\hline Pts/sec: & 20 & \# Cont Pts: & 1589 & \# Dscrt Pts: & 49 \\
\hline
\end{tabular}


WHC-SD-WM-ANAL-048, Rev. 0

\section{APPENDIX F - Point Processing of Discretes}

CPU Utilization

for

Point Processing Functions

with

Discrete Points

\begin{tabular}{|c|c|c|c|c|c|}
\hline $\begin{array}{l}\text { Pt. Proc. } \\
\text { Function }\end{array}$ & & $\begin{array}{l}\text { Average } \\
\text { (10 Min.) }\end{array}$ & $\begin{array}{l}\text { Minimum, } \\
\text { (10 Min.) }\end{array}$ & $\begin{array}{l}\text { Maximum } \\
(10 \text { Mín. }\end{array}$ & $\begin{array}{l}\text { Std Dev } \\
\text { (10 Min.) }\end{array}$ \\
\hline All Funcs & $\% \mathrm{CPU}$ & 25.026 & 23.511 & 28.509 & $2.85 \%$ \\
\hline w/o Logging & $\%$ CPU & 14.682 & 13.226 & 15.788 & $4.15 \%$ \\
\hline W/o Al arm & $\%$ CPU & 14.221 & 12.543 & 20.312 & $5.63 \%$ \\
\hline W/o Pt Proc & $\%$ CPU & 9.63 & 7.424 & 10.883 & $7.11 \%$ \\
\hline w/o Rule & $\%$ CPU & 8.18 & 6.342 & 16.622 & $11.91 \%$ \\
\hline BKGD & $\%$ CPU & 8.042 & 6.474 & 9.268 & $6.64 \%$ \\
\hline $\begin{array}{l}\text { Summary } \\
\text { Breakdown } \\
\end{array}$ & $\% \cdot \mathrm{CPU}$ & & $\begin{array}{l}\text { Pt. Proc. } \\
\text { Breakdown }\end{array}$ & $\% c p u / p t / s e c$ & \\
\hline Pt Proc & 15.40 & $61.5 \%$ & Update Pt. & 0.23 & $29.8 \%$ \\
\hline Rule Proc & 1.45 & $5.8 \%$ & Alarm Chk & 0.02 & $3.0 \%$ \\
\hline I/0 Proc & 0.14 & $0.6 \%$ & Log to Disk & 0.52 & $67.2 \%$ \\
\hline Bkgd & 8.04 & $32.1 \%$ & & & \\
\hline Total: & 25.03 & $100.0 \%$ & Tota1: & 0.77 & $100.0 \%$ \\
\hline Pts/sec: & 20 & \# Cont Pts: & 1589 & \# Dscrt Pts: & 49 \\
\hline
\end{tabular}




$$
\text { WHC-SD-WM-ANAL-048, Rev. } 0
$$

\section{APPENDIX G - Remote Window Processing \\ CPU Utilization \\ for \\ Remote Telewindow ${ }^{\oplus}$ Processing Functions}

Measurements were on a SPARC-20/75 Mhz system on TCP/IP network

\begin{tabular}{|c|c|c|c|}
\hline & & $\begin{array}{l}\text { REMOTE } \\
\text { TELEWINDOW' } \\
\text { PROCESSING } \\
\end{array}$ & \\
\hline Description & Average CPU-\% & Minimum CPU-\% & Maximum CPU-\% \\
\hline 2 Windows & 9.2 & 6.8 & 0.11 \\
\hline 0 Windows & 8.0 & 6.1 & 0.10 \\
\hline DIFFERENCE & 1.2 & & \\
\hline
\end{tabular}

From this we compute the Average CPU usage to be 0.6 CPU-\% per Telewindow ${ }^{\circledR}$. 


\section{DISTRIBUTION SHEET}

\begin{tabular}{|c|c|c|c|c|c|}
\hline \multirow{2}{*}{$\begin{array}{l}\text { To } \\
\text { Distribution }\end{array}$} & \multirow{2}{*}{\multicolumn{3}{|c|}{$\begin{array}{l}\text { From } \\
\text { Waste Tank Surveillance, } \\
\text { Engineering, and Technical } \\
\text { Applications Resources } \\
\end{array}$}} & \multicolumn{2}{|c|}{ Page 1 of 1} \\
\hline & & & & \multicolumn{2}{|c|}{ Date $7 / 16 / 96$} \\
\hline \multirow{2}{*}{\multicolumn{4}{|c|}{$\begin{array}{l}\text { Project Title/Work Order } \\
\text { Tank Monitor and Control System }\end{array}$}} & \multirow{2}{*}{\multicolumn{2}{|c|}{$\begin{array}{l}\text { EDT No. } 615268 \\
\text { ECN No. }\end{array}$}} \\
\hline & & & & & \\
\hline Name & MSIN & $\begin{array}{c}\text { Text } \\
\text { With } \\
\text { All } \\
\text { Attach. }\end{array}$ & $\begin{array}{l}\text { Text } \\
\text { Only }\end{array}$ & $\begin{array}{l}\text { Attach./ } \\
\text { Appendix } \\
\text { Only }\end{array}$ & $\begin{array}{l}\text { EDT/ECN } \\
\text { Only }\end{array}$ \\
\hline D. A. Barnes & $\mathrm{R} 1-80$ & $x$ & & & \\
\hline R. B. Bass & $57-81$ & $x$ & & & \\
\hline T. W. Bohan & S5-04 & $x$ & & & \\
\hline D. J. Born & H6-11 & $x$ & & & \\
\hline D. E. Bowers & $56-01$ & $x$ & & & \\
\hline D. B. Engelman & $16-37$ & $x$ & & & \\
\hline R. G. Geiger & H8-22 & $x$ & & & \\
\hline M. J. Holm & $R 1-80$ & $x$ & & & \\
\hline J. A. Hubbard & $R 2-54$ & $x$ & & & \\
\hline R. W. Jacobson & $R 1-09$ & $x$ & & & \\
\hline J. W. Lentsch & $57-14$ & $x$ & & & \\
\hline R. W. Little & Rl-01 & $x$ & & & \\
\hline D. R. Nunamaker & $T 4-07$ & $x$ & & & \\
\hline L. M. Ollero & $\mathrm{Rl}-0 \mathrm{I}$ & $x$ & & & \\
\hline C. C. Scaief, III & $S 2-01$ & $x$ & & & \\
\hline D. G. Spurling & $\mathrm{R} 1-01$ & $x$ & & & \\
\hline S. J. Washburn & $\mathrm{Rl}-01$ & $x$ & & & \\
\hline TMACS Project File & $\mathrm{R} 1-01$ & $x$ & & & \\
\hline
\end{tabular}

